\title{
Peningkatan Hasil Belajar Tematik Melalui Pendekatan Saintifik Pada Peserta Didik Kelas I A SD Inpres Ende 7 Kecamatan Ende Timur Kabupaten Ende Tahun Pelajaran 2018/2019
}

\author{
Bergita Nirgaya \\ e-mail: bergita_nirgaya@yahoo.com
}

Guru Sekolah Dasar Inpres Ende 7, Ende, NTT

\begin{abstract}
ABSTRAK : Tujuan penelitian ini adalah untuk mengetahui penerapan pembelajaran tematik dengan pendekatan saintifik dan hasil belajar peserta didik kelas IA SD Inpres Ende 7. Jenis penelitian yang digunakan adalah penelitian tindakan kelas dengan teknik pengumpulan data yakni teknik observasi, dan tes. Hasil penelitian menunjukan aktivitas guru pada siklus I belum optimal dalam menumbuhkan pengalaman baru yang bermakna serta penggunaan waktu yang lebih dominan untuk membahas tema secara matematis, belum optimal dalam menyederhakan fenomena umum untuk kemudian menarik simpulan yang spesifik (inductive reasoning) atau sebaliknya fenomena spesifik untuk kemudian menarik kesimpulan secara keseluruhan (deductive reasoning). Ketuntasan hasil belajar sebesar 36, 36\%. Pada siklus II terjadi peningkatan aktivitas guru dan peserta didik dan ketuntasan $100 \%$, dengan rata-rata 78,18. Disimpulkan pembelajaran tematik memberikan muatan bagi peserta didik untuk memiliki keterampilan berpikir komprehensif (multi aspek), memiliki keterkaitan secara rasional dan empirik. Pendekatan saintifik (scientific approach) memberikan ruang bagi peserta didik mengamati, menanya, mencoba, mengolah, menyajikan, menyimpulkan, dan mencipta. Dengan demikian peserta didik akan menggunakan keterampilan menginvestigasi dan atau inquiry terhadap suatu atau beberapa fenomena/gejala. Disarankan kepada guru untuk mengoptimalkan tahap-tahap pembelajaran tematik dengan pendekatan saintifik untuk membiasakan peserta didik berpikir kritis secara komprehensif berlandaskan pada rasionalitas dan empirik.
\end{abstract}

Kata kunci : hasil belajar, pendekatan saintifik.

ABSTRACT: The purpose of this study was to determine the application of thematic learning with scientific approaches and learning outcomes of class IA students of SD Inpres Ende 7. The type of research used was classroom action research with data collection techniques namely observation techniques, and tests. The results showed that the teacher's activity in the first cycle was not optimal in fostering new experiences that were meaningful and more dominant use of time to discuss themes mathematically, not optimal in making general phenomena available to later draw specific conclusions (inductive reasoning) or otherwise specific phenomena later draw conclusions as a whole (deductive reasoning). Learning outcomes are 36, 36\%. In the second cycle there was an increase in teacher and student activities and $100 \%$ completeness, with an average of 78.18. It is concluded that thematic learning provides a charge for students to have comprehensive thinking skills (multi aspects), having a rational and empirical relationship. Scientific approach (scientific approach) provides space for students to observe, ask, try, process, present, conclude, and create. Thus students will use the skills to investigate and or inquiry against a phenomenon or symptoms. It is recommended to teachers to optimize the stages of thematic learning with a scientific approach to familiarize students with critical thinking comprehensively based on rationality and empiricism.

Keywords: learning outcomes, scientific approach. 


\section{PENDAHULUAN}

Pembelajaran tematik merupakan penerapan konsep belajar sambil melakukan sesuatu (learning by doing) untuk mengkaji satu tema/topik tertentu dan kemudian dielaborasi ke berbagai aspek atau keterpaduan konsep interdisipliner mata pelajaran yang biasa diajarkan di sekolah. Pembelajaran tematik memberikan ruang bagi peserta didik belajar berinteraksi dengan lingkungannya baik lingkungan fisik maupun lingkungan sosial sehingga memperoleh pengetahuan dan pengalaman. Keterkaitan (linkages) dan keterhubungan (relationship) antar berbagai disiplin ilmu memungkinkan peserta didik memperoleh banyak informasi walaupun peserta didik belum bisa mengelaborasi pengetahuan itu sesuai dengan bidang-bidang ilmu-ilmu tertentu. Tetapi yang diterima peserta didik adalah satu kesatuan dan keseluruhan.

Kurikulum 2013, mengamanatkan penerapan pembelajaran tematik dengan menggunakan pendekatan saintifik/ilmiah secara integratif. Konsepsi pendekatan saintifik (scientific approach) dalam pembelajaran tematik meliputi komponen: mengamati, menanya, mencoba, mengolah, menyajikan, menyimpulkan, dan mencipta. Hal tersebut mencitrakan tindakan investigasi/inquiry terhadap suatu atau beberapa fenomena atau gejala, memperoleh pengetahuan baru berbasis pada bukti-bukti dari objek yang dapat diobservasi, empiris, dan terukur dengan prinsip-prinsip penalaran yang spesifik.

Pembelajaran berbasis pendekatan saintifik itu lebih efektif hasilnya dibandingkan dengan pembelajaran tradisional. Hasil penelitian membuktikan bahwa pada pembelajaran tradisional, retensi informasi dari guru sebesar $10 \%$ setelah lima belas menit dan perolehan pemahaman kontekstual sebesar $25 \%$. Pada pembelajaran berbasis pendekatan ilmiah, retensi informasi dari guru sebesar lebih dari $90 \%$ setelah dua hari dan perolehan pemahaman kontekstual sebesar 50-70 \% (Atsnan dan Gazali, 2013).

Pembelajaran tradisional patut diakui menimbulkan kepasifan bagi peserta didik dalam pembelajaran seperti yang dialami peserta kelas IA SD Inpres Ende 7, bahwasanya hasil belajar peserta didik kelas IA dengan sistem tematik atau terpadu masih rendah. Salah satu yang menjadi pertimbangan para guru yakni kemudahan dalam persiapan maupun dalam pelaksanaan kegiatan pembelajaran. Impliksi yang diperoleh secara langsung oleh peserta didik yang daya tangkapnya cepat, kadang merasa bosan jika pelajaran yang diajarkan diulang secara terus menerus. Di sisi lain hasil riset tersebut di atas menjadi rujukan untuk melakukan perbaikan pembelajaran dalam rangka mengatasi rendahnya hasil belajar.

\section{METODE PENELITIAN}

Berlandaskan pada variabel penelitian maka penelitian ini merupakan penelitian tindakan kelas pada guru dan peserta didik kelas IA SDI Ende 7 Semester II Tahun Ajaran 2016/2017. Data diperoleh dengan teknik observasi berkaitan dengan keadaan dan suasana pembelajaran tematik dengan pendekatan saintifik yang dilakukan oleh guru dan peserta didik serta teknik tes untuk mengetahui hasil belajar. Selanjutnya data yang diperoleh dianalisis secara kualitatif dan kuantitatif dengan menggunakan alur tindakan model Kemmis \& Mc Taggart, (dalam Kunandar, 2008: 70-75), secara garis besar terdapat empat tahapan yang dilalui, yaitu (1) perencanaan, pelaksanaan, (3) pengamatan, dan (4) refleksi.

\section{PEMBAHASAN}

Merujuk pada hasil pengamatan aktivitas guru pada siklus I menunjukkan tindakan penerapan pembelajaran tematik yang belum optimal yakni menumbuhkan pengalaman baru yang bermakna serta 
penggunaan waktu yang lebih dominan untuk membahas tema secara matematis. Selanjutnya pada penerapan pendekatan saintifik dalam pembelajaran belum optimal dalam konteks penyederhaan fenomena umum untuk kemudian menarik simpulan yang spesifik (inductive reasoning) atau sebaliknya fenomena spesifik untuk kemudian menarik kesimpulan secara keseluruhan (deductive reasoning).
Penilaian hasil belajar menggunakan tes menunjukkan hasil yang belum memuaskan atau peserta didik dominan belum mencapai standar ketuntasan yakni sebanyak 14 peserta didik atau 63,64\%, atau sebaliknya \% ketuntasan sebesar 36 , $36 \%$ yang diraih oleh 8 peserta didik. Perolehan nilai tertinggi pada siklus I adalah 80 dan nilai terendah 40 , dengan rata-rata $56,82 \%$.

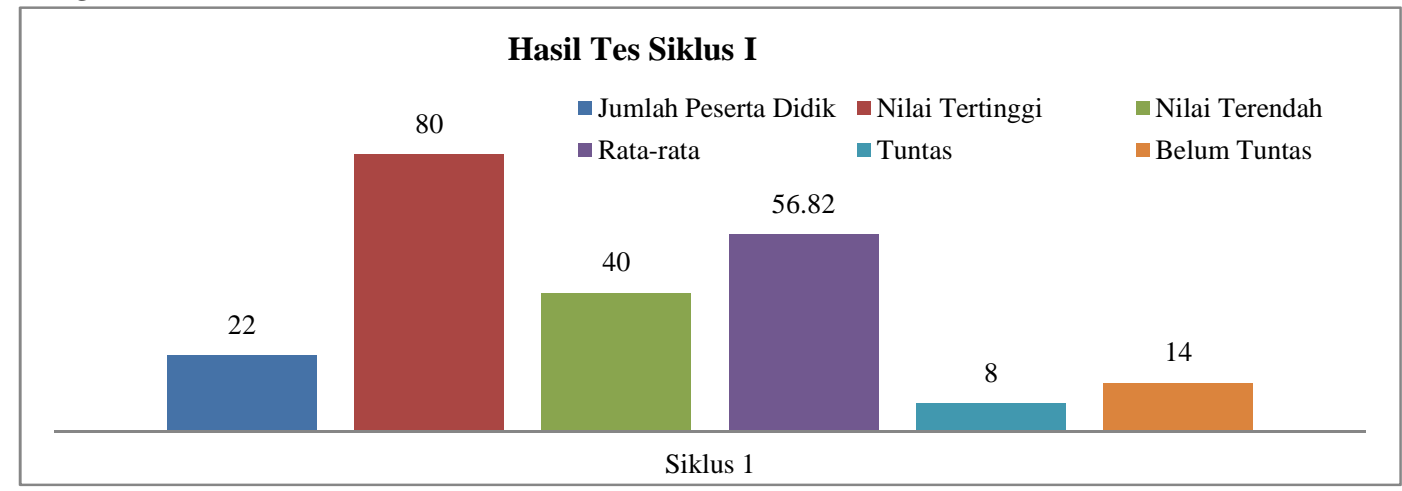

Kesulitan belajar yang digambarkan dengan hasil belajar diatas selain dipengaruhi oleh aktivitas guru juga dipengaruhi oleh keterbatasan peserta didik dalam menalari dan memadukan tema secara faktual dan teoretis pada lingkup materi matematika dan bahasa. Artinya pembahasan suatu topik dikaitkan dengan kondisi yang dihadapi siswa atau ketika siswa menemukan masalah dan memecahkan masalah yang nyata dihadapi siswa dalam kehidupan sehari-hari dikaitkan dengan topik yang dibahas. Selanjutnya dalam konteks saintifik, kesulitan menalari di atas didukung oleh kesulitan/keterbatasan peserta didik; menyimak, malu/takut bertanya tentang hal yang belum dipahami, mengolah informasi, berkomunikasi dengan bahasa yang baik dan benar.
Keterbatasan tindakan dan hasil belajar yang terdapat pada siklus I menjadi acuan refleksi dan perencanaan perbaikan tindakan pada siklus II. Secara umum tindakan dalam pembelajaran pada siklus II menunjukkan adanya peningkatan aktivitas guru dan peserta didik. Hal tersebut ditunjukkan dengan optinalisasi kekurangan dalam aktivitas mengelola pembelajaran oleh guru dan keaktifan peserta didik dalam proses pembelajaran. Hal lain perolehan nilai peserta didik tertinggi 100, dengan rata-rata 78,18. Dengan demikian \% ketuntasan mencapai $100 \%$, atau memeroleh nilai diatas ketuntasan minimal.

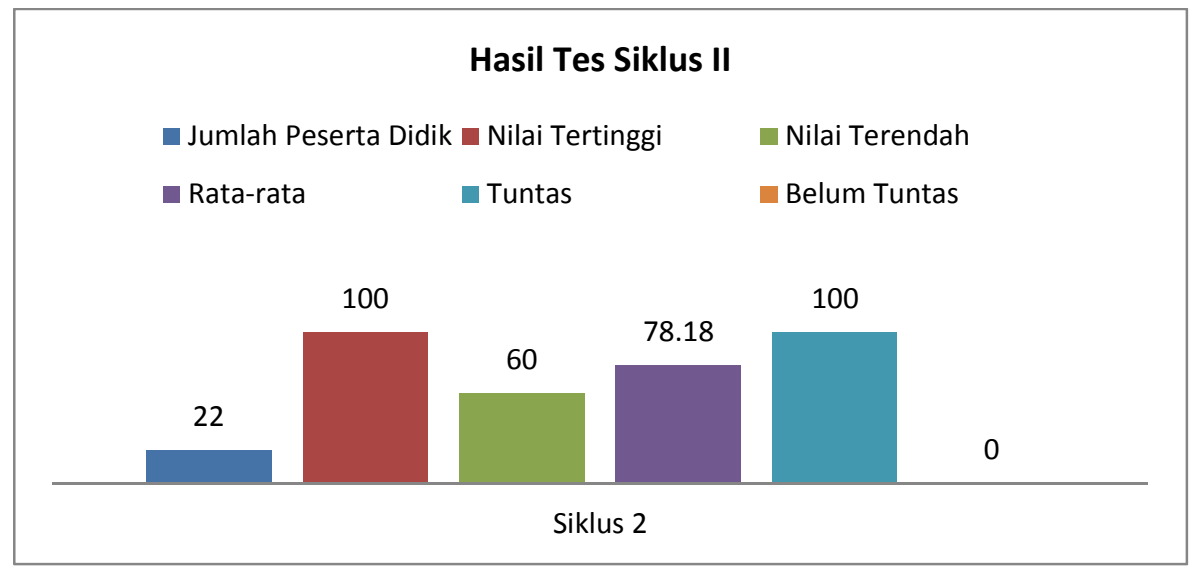


Berdasarkan Permendikbud Nomor 81A Tahun 2013 tentang Implementasi Kurikulum Pedoman Umum Pembelajaran, kegiatan pembelajaran dirancang untuk memberikan pengalaman belajar yang melibatkan proses mental dan fisik melalui interaksi antar peserta didik, peserta didik dengan guru, lingkungan dan sumber belajar lainnya dalam rangka pencapaian KD.

Sesuai dengan tujuan penelitian yakni memperoleh informasi dan gambaran tentang pelaksanaan pembelajaran tematik dengan pendekatan saintifik pada peserta didik kelas IA SDI Ende 7 Semester II Tahun Ajaran 2016/2017, peneliti memperoleh gambaran bahwa pelaksanaan pembelajaran tematik dengan pendekatan saintifik telah terlaksana walaupun belum optimal karena dalam penyampaian materi tidak terlihat jelas pemisahan mata pelajaran yang satu dengan yang lainnya. Ketidakjelasan pemisahan materi menjadi salah satu karakteristik dari pembelajaran tematik seperti yang dikemukanan oleh Rusman, (2014: 258-259) karakteristik pembelajaran tematik adalah berpusat pada siswa, memberi pengalaman langsung, pemisahan mata pelajaran tidak begitu jelas, menyajikan konsep dari berbagai mata pelajaran, bersifat fleksibel hasil pembelajaran sesuai dengan minat dan kebutuhan siswa., menggunakan prinsipprinsip sambil bermain dan menyenangkan.

Pembelajaran tematik dengan pendekatan saintifik mencitrakan penalaran yang ditimbulkan oleh pengindaraan atau pengalaman faktual pada setiap peserta didik yang beranekaragam. Dengan demikian penalaran merupakan aktivitas berpikir logis sebagai akibat adanya pengindraan dalam pola tertentu atau menurut logika tertentu, serta analitik.

Berpikir secara logis identik berpikir dengan menggunakan logika, rasional atau masuk akal. Dengan berpikir logis, peserta didik akan mampu membedakan dan mengkritisi kejadian-kejadian yang terjadi itu secara rasional dan sesuai dengan ilmu pengetahuan. Cara berpikir logis menunjukkan cara berpikir deduktif dan berpikir induktif. Logika deduktif adalah penarikan kesimpulan yang diambil dari proposisi umum ke proposisi khusus. Selanjutnya logika induktif kebalikan dari logika deduktif. Jenis logika ini harus mengikuti penalaran yang berdasarkan pengalaman atau kenyataan. Artinya, jika tidak ada bukti maka kesimpulannya belum tentu benar atau pasti. Dengan demikian, suatu kesimpulan yang tidak berdasarkan pengalaman atau kenyataan lewat tangkapan panca indra, tidak akan mempercayai.

Berpikir logis juga identik dengan kemampuan berpikir kritis (directed thinking) sehingga peserta didik mampu mengolah fenomena-fenomena yang diterima oleh indera hingga memunculkan berbagai pertanyaan untuk dicari jawabannya. Berpikir kritis sebagai aktivitas mental dalam mengevaluasi kebenaran sebuah pernyataan yang ditunjukkan dengan putusan untuk menerima, menyangkal, atau meragukan kebenaran sebuah pernyataan. Mulyasa (2013:103) mengemukakan pelaksanaan pembelajaran harus berangkat dari proses dialogis antar sesama subjek pembelajaran sehingga melahirkan pemikiran kritis dan komunikasi. mengikuti prosedur memulai pelajaran, mengelola kegiatan belajar mengajar, mengorganisasikan waktu, siswa, dan fasilitas belajar, melaksanakan penilaian proses dan hasil pelajaran, dan mengakhiri pelajaran. Lebih lanjut ditandasakan pula bahwa dalam pelaksanaan pembelajaran tematik disesuaikan dengan pendekatan saintifik dengan langkah mengamati, menanya, mencari informasi, mengasosiasi, dan menkomunikasikan.

Paparan tersebut di atas menunjukkan penalaran ilmiah yang mengintegrasikan penalaran deduktif dan induktif, dimana penalaran deduktif terkait dengan rasionalisme dan penalaran induktif terkait dengan 
empirisme. Secara rasional, ilmu menyusun pengetahuannya secara konsisten dan kumulatif, sedangkan secara empiris, ilmu memisahkan antara pengetahuan yang sesuai fakta dengan yang tidak. Karena itu sebelum teruji kebenarannya secara empiris semua penjelasan rasional yang diajukan statusnya

\section{KESIMPULAN DAN SARAN}

Berlandaskan pada deskripsi hasil dan pembahasan di atas, disimpulkan bahwa pembelajaran tematik memberikan muatan bagi peserta didik untuk memiliki keterampilan berpikir komprehensif (multi aspek) yang memiliki keterkaitan secara rasional dan empirik, berimplikasi pada pengujian hipotetis. Hipotesis yang terdapat sebuah penalaran kemudian diuji dengan pendekatan saintifik (scientific approach) dengan cara mengamati, menanya, mencoba, mengolah, menyajikan, menyimpulkan, dan mencipta. Dengan demikian peserta didik akan menggunakan keterampilan menginvestigasi dan atau inquiry terhadap suatu atau beberapa fenomena atau gejala, untuk memperoleh pengetahuan baru berbasis pada bukti-bukti dari objek secara hanyalah bersifat sementara atau yang biasa disebut hipotesis. Dengan demikian konklusi dari pendekatan saintifik dalam pembelajaran tematik sesungguhnya menstimuli kreatifitas berpikir peserta didik secara rasional dan menemukan/menguji kebenaran secara faktual/empiris. terukur dengan prinsip-prinsip penalaran deduktif maupun induktif. Proses pembelajaran tematik dengan pendekatan saintifik dipandang efektif memberikan hasil belajar yang memenuhi bahkan melebihi batas ketuntas minimal, serta efisien karena dilakukan dalam dua siklus.

Melihat proses dan hasil yang diperoleh dalam pembelajaran, maka disarankan kepada guru untuk mengoptimalkan perencanaan dan pelaksanaan tahap-tahap pembelajaran tematik dengan pendekatan saintik. Selain itu pembiasaan menerapkan pembelajaran tersebut memungkinkan peserta didik berpikir kritis secara komprehensif berlandaskan pada rasionalitas dan empirik.

\section{Daftar Pustaka}

Atsnan, M. F. \& Gazali, R. Y. (2013). Penerapan Pendekatan Scientifik dalam Pembelajaran Matematika SMP Kelas VII Materi Bilangan (Pecahan). Prosiding Seminar Nasional Matematika, ISBN : 978-979-16353-9-4.

Kunandar. (2010) Penelitian Tindakan Kelas (Jakarta: Rajawali Pers, 2010), 70-75

Mulyasa. (2013). Pembelajaran Tematik. Jakarta: Bumi Aksara.

Rusman. (2014). Pembelajaran Tematik Terpadu Teori, Praktik dan Penilaian. Jakarta: Raja Grasindo Persada 